\title{
Clinical aspects of trace elements: Zinc in human nutrition - A biochemical and physiological perspective
}

\author{
MiCHELLE M PLUHATOR MSC, ALAN BR THOMSON MD PHD FRCPC FACP FRS FACC, RICHARD N FEDORAK MD FRCPC
}

\begin{abstract}
MM PluHATOR, ABR THOMSON, RN FEDORAK. Clinical aspects of trace elements: Zinc in human nutrition - A biochemical and physiological perspective. Can J Gastroenterol 1995;9(5):251-256. The tremendous technological advances in trace element analysis seen in recent years have stimulated and facilitated research in a number of disciplines including microbiology, nutrition, agriculture, clinical medicine and, most recently, psychology. The importance of trace elements to human health is receiving greater attention as clinical cases of deficiency and toxicity are described. Zinc has been recognized as an essential trace element for humans since the early 1960s. It has been found to play a critical role in the physiological and biochemical well-being of humans. This review discusses the tissue distribution, concentration and intracellular binding of zinc in healthy humans. (Other reviews in this five-part series will appear in following issues.) The biochemical roles of zinc, including its involvement in the actions of metalloenzymes, cell synthesis, wound healing, growth, reproduction, hormone metabolism, cellular structural stability and immunological processes, are highlighted in order to provide an understanding of the unique and extensive role zinc plays in the biochemistry of the human body.
\end{abstract}

Key Words: Action mechanism, Biochemistry, Trace element, Zinc

Aspects cliniques, biochimiques et physiologiques des éléments traces : zinc et nutrition humaine

RÉSUMÉ : Les immenses progrès accomplis au chapitre de l'analyse des éléments traces depuis quelques années ont encouragé et stimulé la recherche dans certaines disciplines, notamment, en microbiologie, en nutrition, en agriculture, en médecine clinique, et plus récemment, en psychologie. L'importance des éléments traces pour la santé humaine fait l'objet d'une attention croissante, à mesure que la science parvient à décrire les cas cliniques des carences ou des intoxications. Depuis le début des années soixante, on sait que le zinc est un voir page suivante \section{Alberta}

Division of Gastroenterology, Department of Medicine, University of Alberta, Edmonton,

Correspondence: Dr RN Fedorak, Division of Gastroenterology, Department of Medicine, University of Alberta, 519 Robert Newton Research Building, Edmonton, Alberta T6G 2C2.

Telephone 403-492-6941, Fax 403-492-3744, e-mail: richard.fedorak@ualberta.ca

Received for publication August 16, 1994. Accepted January 23, 1995
$\mathrm{T}$ HISREVIEW DISCUSSESTHETISSUE distribution, concentration and intracellular binding of zinc in healthy humans. It is the first of a five-part series that examines zinc in terms of its biochemistry and physiology, metabolism, dietary requirements, nutritional assessment, and states of excess and deficiency.

The term 'trace element' was coined half a century ago when scientists began describing a number of mineral elements that occur in minute amounts ('traces') in biological materials (1). These low concentrations made measurement of the elements virtually impossible given the analytical methods available at the time. However, the tremendous technological advances in recent years have provided the analytical means for trace elements to be measured with speed, sensitivity and precision.

Trace elements, as noted above, can be distinguished from major mineral elements in that they exist and function in living organisms in very small concentrations. 'Trace' should not be taken to mean 'unimportant' because a number of trace elements act as vital catalysts for essential enzymes, stabilize membranes, provide tissue structure and are involved in hormonal function. At present 22 mineral elements are considered essential for life (2). 
élément trace essentiel à l'homme. Il joue en effet un rôle central dans l'équilibre physiologique et biochimique de l'organisme humain. Cet article passe en revue la distribution tissulaire, la concentration et les liaisons intracellulaires propres au zinc chez l'humain en santé. (D'autres synthèses seront présentées dans cette série de cinq articles.) Les rôles biochimiques du zinc, incluant son rapport avec les métallo-enzymes, la stabilité de la structure cellulaire et les processus immunologiques sont soulignés, pour une meilleure compréhension du rôle unique et complexe du zinc dans la biochimie de l'organisme humain.

TABIE 1

Approximate zinc content of major tissues in the nomal human

\begin{tabular}{lc}
\hline Tissue & $\begin{array}{c}\text { Znc content } \\
\text { (mg/ kg dry weight) }\end{array}$ \\
\hline Liver & $141-245$ \\
Kidney & $184-230$ \\
Lung & $67-86$ \\
Skeletal musc le & $197-226$ \\
Pancreas & $115-135$ \\
Bone & 218 \\
Prostate & 520 \\
Eye (retina) & 571 \\
\hline
\end{tabular}

Reproduced from reference 58

Trace metals are considered essential when an inadequate intake produces an impairment of function, and when supplementation with the element reverses the impaired function or prevents impairment $(3,4)$. It is likely that some of the 20 to 30 elements considered to be toxic substances or contaminants will be found to be essential in small amounts.

Trace element deficiencies may arise from both inadequate dietary intake and decreased bioavailability, or they may be associated with disease states in which impaired absorption, excessive excretion, and/or excessive utilization occurs.

\section{BIOCHEMISTRY OF ZINC}

Zinc has been recognized as an essential nutrient for humans since the early 1960s $(5,6)$. The human body normally contains 2 to 3 g of zinc $(2,7)$, and zinc is found in all tissues in varying concentrations; the highest concentrations occur in the retina, prostate, prostatic secretions and spermatozoa. Three-quarters of the total bodily amount can be found in the skeleton, from which it is slowly removed over time (2). Significant amounts also appear in the liver, kid- ney and skeletal muscle $(8,9)$ (Table $1)$. In the blood, zinc is concentrated within the erythrocytes. A small amount appears in blood serum (2) which contains a zinc concentration of approximately $18.4 \mathrm{~mol} / \mathrm{L} \mathrm{(10).} \mathrm{Zinc}$ in the form of an intracellular ion accounts for over $95 \%$ of total body zinc (11). Intracellular zinc is predominantly found in the cytosol; about 10 to $20 \%$ is seen in the nucleus, and smaller amounts are present in the microsomal and mitochondrial fractions (12). A smaller amount of zinc is found in the cell membrane, and it has been suggested that the fraction of intracellular zinc specifically bound to membranes may play an important role in the onset of zinc deficiency symptoms (13).

The chemical state of zinc within cells is not clearly understood. Biologically, zinc is found attached to organic ligands and proteins rather than free in solutions as a metallic ion. However, it appears that zinc may play a controlling role in some enzymes rather than being firmly bound as an integral part of the molecule (11). This finding may imply that a readily available zinc 'pool' exists within cells or it may suggest that binding substances assist in enzyme activation by zinc (11). The characteristics of these pools or substances remain unclear. A number of researchers have reported that cytosolic zinc of a number of different tissues is distributed in three or four pools within the cell, and that these pools consist of mainly larger weight molecular proteins, including many of the zinc metalloenzymes (14).

It appears that there are age-related differences in zinc distribution. There are considerable differences in the relative sizes of tissues, as well as in their zinc content, between neonates and the adult human. In particular, the zinc content of liver and bones is much higher in newborns (about 25 to $40 \%$ of the total body zinc) and the relative size of the liver is much larger $(11,15)$. Much of this zinc may be used for soft tissue growth since neonatal bones undergo comprehensive remodelling after birth (11).

There is little information on zinc nutriture in the elderly. Some studies have shown a decline in plasma zinc with age (16), while others have failed to observe such a change $(17,18)$. Whether age affects zinc requirements is not known. A few studies have investigated the relationship between zinc nutriture and the immune function of elderly persons. This subject is important because the deterioration of $\mathrm{T}$ cell immune function is associated with both zinc deficiency and ageing. There is, thus, the possibility that poor zinc status contributes to $\mathrm{T}$ cell immune dysfunction (16).

\section{PHYSIOLOGICAL ROLES OF ZINC}

Metalloenzymes: The first discussion of a specific biological function dependent on zinc came with the discovery in 1940 that zinc was essential to carbonic anhydrase's mechanism of action (6). Since then, zinc has proved to be an important constituent of more than 20 human metalloenzymes $(9,19,20)$. Zinc is thought to act at the catalytic site, forming highly specific associations with metalloenzymes. Zinc-dependent metalloenzymes are involved in a variety of metabolic activities, including those of carbohydrate, fat and protein metabolism (21). Zinc-dependent metalloenzymes are also necessary for nucleic acid synthesis and degradation $(9,20)$; zinc is thus vital to the fundamental processes of cell replication and differentiation.

Protein synthesis: Zinc is essential to both DNA and RNA synthesis $(5,9,20)$. Its primary effect is thought to be through zinc-dependent enzymes that regulate the biosynthesis and catabolic rates of DNA and RNA (9). Studies have consistently noted that both total DNA and its incorporation rates are reduced as a consequence of zinc deficiency $(22,23)$. It is possible that this reduction may be primarily linked to the ac- 
tivities of the DNA-synthesizing enzymes DNA polymerase and thymidine kinase. Numerous investigators have showed that decreased DNA synthesis is associated with the decreased specific activity of both enzymes (2426), and Duncan and Hurley (27) have demonstrated that zinc deficiency results in reduced DNA polymerase activity in rats. Many other investigators have shown that zinc deficiency in animals impairs the incorporation of labelled thymidine into DNA (9). This decreased enzyme activity may ultimately be responsible for the growth retardation linked to zinc deficiency.

Pardee et al (28) proposed that zinc plays a role in cell division. These researchers have suggested that zinc may have a role in stabilizing a multiprotein 'replicase' complex consisting of such enzymes as DNA polymerase, thymidine kinase and thymidine synthase before the incorporation of deoxynucleotides into DNA. Without zinc, the spatial relationships among the various components may be modified in such a way as to prevent proper DNA synthesis. In this same article, Pardee et al provide evidence that shows that a final regulatory protein must be synthesized and united with the replicase complex before the replicase can function. It is possible that insufficient quantities of zinc may impede the transcription of mRNA that is required for synthesis of adequate amounts of this protein.

Zinc's regulation of the cell cycle may occur after DNA synthesis at the point of chromatin decondensation before mitosis and during assembly of the mitotic spindle via zinc's effects on microtubule assembly. Sen and Crothers (29) showed that zinc has the ability to modulate the condensation/decondensation of chromatin. Zinc can stimulate the polymerization of purified tubulin in vitro (30). It is thus likely that zinc plays a critical role in regulation of the cell cycle, and that a deficiency can disrupt the normal cell synthetic processes.

Recent research has focused on zinc's interaction with various chromatin components. It has been demonstrated that zinc can stabilize the DNA double helix with respect to thermal denaturation (31). In addition, zinc can promote recombination of singlestranded DNA into its native doublestranded form through its ability to bind to both the phosphate backbone and nucleoside bases of DNA (31). Zinc also promotes conformational transformations of DNA (32). Because zinc deficiency can alter the conformation of chromatin, RNA polymerase access to various genes may be impeded by a lack of zinc (30). Castro and colleagues (33) demonstrated that an alteration in the amounts of histone $\mathrm{H} 1^{\circ}$ occurs in zincdeficient rat liver. Because histones are necessary to the proper structure and functioning of chromatin, these alterations may explain some of the abnormal metabolic processes occurring in zinc-deficient organisms. However, the mechanism by which zinc affects histone metabolism is not known.

Nonhistone proteins responsible for gene expression, such as RNA polymerase, can also be affected by zinc deficiency. In one study, Euglena gracilis cells grown in a zinc-sufficient medium produced three distinct RNA polymerases, while cells grown in zincdeficient media synthesized only one RNA polymerase, which was different from the other three (34). It is not known whether zinc affects the transcription of RNA polymerase genes directly or indirectly. Some researchers have been investigating a direct role for zinc in gene transcription. A xenopus transcription factor has been identified as a zinc metalloenzyme (30). This suggests that some genes may be partially or fully regulated by zinc enzymes. Given the past and current evidence, it appears realistic to presume that some of the defects caused by zinc deficiency occur as a result of altered chromatin metabolism. This possibility may be of particular importance in the case of the fetus, where synchronized timing and expression among genes are critical for normal development.

RNA polymerases contain more than $1 \mathrm{~mol}$ of zinc/mol protein (30). It is reasonable to suggest that zinc has both structural and catalytic functions in RNA polymerases, and that a deficiency of dietary zinc can lead to a reduction in the activity or function of RNA po- lymerases (30). Terhune and Sanstead (35) have demonstrated that RNA polymerase activity is significantly lower than normal in the liver of postnatal zinc-deficient rats. Zinc is now known to be a normal constituent of RNA; it is also important to the stabilization of ribosome conformation (30). Both of these macromolecules are present in pre-initiation and initiation complexes; it is, therefore, likely that zinc plays an essential role in stabilizing these structures. In a number of studies, zinc-deficient organisms were found to have decreased amounts of, and reduced synthetic rates for, RNA (30). It has been suggested that these lowered RNA rates and amounts are mainly the result of increased ribonuclease activity, which in turn is regulated by zinc (or, in this case, a lack thereof). Taken as a whole, the information on abnormal gene expression and RNA metabolism in zinc deficiency states strengthens the hypothesis that zinc deficiencies alter protein metabolism. Defects in protein synthesis are detrimental to the human fetus, as well as to children and adults.

Wound healing: Zinc's involvement in the cell cycle, as discussed above, is integral to its role in wound healing. Studies have confirmed that zinc accumulates around the wound (where cell division takes place most vigorously), particularly during the initial week of healing (36). Supplementary zinc, however, only appears effective in promoting healing when small amounts are ingested and low plasma zinc levels are present. There is no evidence that high levels of zinc ingestion provide any additional advantages (2,36).

Growth and reproduction: Because zinc has its most profound influence on rapidly growing tissues, its effect on growth and reproduction is important. Zinc is necessary for adequate gonadal development and growth response from infancy to adulthood (2). Zinc deficiency causes growth retardation in infants, children and adolescents. A mirror relationship exists between plasma zinc levels and the growth index, an indicator of growth velocity (9). Animal studies have shown a graded response in the impairment of growth ve- 


\begin{tabular}{l} 
TABIE 2 \\
Physiological roles of zinc \\
\hline Metalloenzymes \\
DNA/RNA synthesis \\
Wound healing \\
Growth \\
Reproduction \\
Hommone action (eg, insulin) \\
Immunological competence \\
\hline
\end{tabular}

locity when dietary zinc was progressively decreased from the minimum level required to maintain maximal growth velocity (37). Studies conducted by both Hambidge (37) and Walravens et al (38) have shown consistent and significant positive effects of zinc supplementation (in physiological doses of $5 \mathrm{mg} /$ day) on linear growth increments for mildly zinc-deficient children. A significant difference in linear growth rates between zincsupplemented and placebo-treated children was invariably observed for males but not females (12). The reason for this sex-linked difference is unclear. Additionally, the direct local effects of zinc deficiency on bone epiphyses are thought to reduce longitudinal growth (39). Depletion of zinc body stores may occur during growth spurts. Thus, children and adolescents would benefit from an increased zinc intake during such periods (9).

Zinc deficiency may depress growth rates through several different mechanisms. At a molecular level, several of the enzymes required for nucleic acid synthesis either contain zinc or are zinc-dependent, and relatively large amounts of zinc are required for new tissue synthesis. Additionally, decreased food intake is an early and notable feature of experimental zinc deficiency (1). Some of zinc's effects on growth may be mediated through changes in the production or secretion of somatomedin. Somatomedin is thought to mediate the skeletal growthpromoting effect of growth hormone. It has been proposed that zinc deficiency may both decrease the effectiveness of growth hormone in stimulating somatomedin production and directly decrease the biological effectiveness of somatomedin in stimulating cartilage growth (39).

Although there have been a substantial number of investigations of male sex hormones and spermatogenesis, little is known about the effects of zinc on the sex hormones of the nonpregnant female. Zinc is important to male testicular function, affecting both spermatogenesis and the production of testosterone by the Leydig's cells. Zinc supplementation has been shown to reverse abnormalities of sexual maturation and hypogonadism in human males (9). Although hypogonadism in zinc-deficient males appears to be more common than ovarian dysfunction in zinc deficient-females (9), zinc does play an important role in pregnancy (40) due to its involvement in cellular growth and maturation, its action as an antibacterial and antiviral agent in amniotic fluid, and the positive correlations that exist between maternal serum zinc concentration and birth weight (41).

Insulin function: Zinc is involved in the action of insulin, thereby affecting glucose tolerance $(2,9)$. A delayed $a b-$ sorption of glucose has been demonstrated in zinc-deficient patients (42). It has been suggested that the rate of insulin secretion in response to glucose stimulation is reduced during zinc deficiency (9). Additionally, it is thought that zinc participates in the storage of insulin in the beta cells and that the amount of insulin stored in zincdeficient subjects is decreased (9). Alternatively, an increase in the degradation of insulin may account for the decrease in glucose tolerance (9). Depressed serum zinc and hyperzincuria are associated with type I and type II diabetes $(43,44)$. Increased urinary excretion of zinc is also positively related to glucose excretion.

Immunological competence: Numerous clinical reports have suggested an association between zinc deficiency and impaired immune competence. In humoral immunity, the interleukin-1 signal, which acts to stimulate helper $\mathrm{T}$ cells and pre-beta cells, causes a rapid redistribution of zinc from the plasma pool to the liver, bone marrow and thymus (45). The reduction in plasma zinc may be critical for phagocytic cell activation, while the stimulation of zinc uptake by the thymic and bone marrow tissues may suggest a critical need for this element during $T$ and beta cell generation (45). The production and/or action of some cytokines is thought to be zinc-dependent (45). For example, the production and/or membrane-binding of interleukin-1, interleukin-2 and interferon may be zinc-dependent (4648). In the case of cell-mediated immunity, zinc deficiency has not been shown to affect the complement system negatively (45). However, zinc at higher levels of the normal physiological range inhibits the complement cascade (49). Thus, the reduction in plasma zinc levels seen following an infection may be a positive consequence for this branch of the immune system.

The production of $\mathrm{T}$ lymphocytes is impaired in zinc deficiency states $(4,45)$. Whether zinc deficiency has a differential effect on specific $T$ cell subsets is currently an area of controversy. Zinc deficiency often presents with a loss of lymphoid tissue mass exceeding that of other body tissues (50). Chronic zinc deficiency will result in atrophy of the entire organ (51). The effects of zinc deficiency on $\mathrm{T}$ cell maturation have been attributed to a possible reduction in the activity of deoxyribonucleotidyltransferase, a zinccontaining DNA polymerase found in high concentrations in mature thymocytes (52). It is also possible that zinc deficiencies may alter thymic epithelial function and impair thymic hormone production, the activities of which, in turn, would inhibit $\mathrm{T}$ cell maturation in the thymus and periphery (53). In addition, overall responsiveness to $T$ cell-independent antigens, as well as to T cell-dependent mitogens, may be noticeably inhibited in cases of zinc deficiency $(45,51)$.

A zinc deficiency may directly influence lymphocyte proliferation. The in vitro stimulation of blast transformation to mitogens such as phytohemagglutinin can be inhibited by zinc-chelating agents (45). Zinc acts as a mitogen to both $\mathrm{T}$ and beta cells $(5,9,45)$. Flynn $(47)$ has suggested that zinc deficiency may affect $\mathrm{T}$ cell prolif- 
eration by reducing the production of cytokines responsible for proliferation, by interfering with the processing of antigens by accessory cells or by causing a loss of cell function or 'activation state' (45).

Delayed-type hypersensitivity, which depends on the interaction between effector $T$ cells and macrophages, is reduced in zinc-deficient animals (51, 54). Macrophage function can be inhibited in zinc-deficient animals (55). Defects in macrophage function include a decreased ability to take up the target and kill it; this decrease is probably due to the limitation of zinc activity in a critical process such as maintaining membrane integrity or tubulin-mediated phagocytosis (55). Decreased natural killer cell activity

\section{REFERENCES}

1. Underwood EJ. Trace Elements in Human and Animal nutrition, 4th edn. New York: Academic Press, 1977.

2. Guthrie HA. Micronutrient elements. In: Introductory Nutrition, 7th edn. Toronto: Times Mirror/Mosby College Publishing, 1989:289-335.

3. Mertz W. The essential trace elements. Science 1981;213:1332-8.

4. Burch RE, Hahn HKJ. Trace elements in human nutrition. Med Clin North Am 1979;63:1057-68.

5. Ronaghy HA. The role of zinc in human nutrition. World Rev Nutr Diet 1987;54:237-54.

6. Prasad AS. Discovery and importance of zinc in human nutrition. Fed Proc 1984;43:2829-34.

7. Health and Welfare Canada. Nutrition Recommendations. Ottawa: Canadian Government Publishing Centre, 1990.

8. Gordon EF, Gordon RC, Passal DB. Zinc metabolism: basic, clinical, and behavioral aspects. J Pediatr 1981;99:341-9.

9. Prasad AS. Clinical, endocrinological and biochemical effects of zinc deficiency. Clin Endocrinol Metab 1985;14:567-89.

10. Wada L, Turnlund JR, King JC. Zinc utilization in young men fed adequate and low zinc intakes. J Nutr 1985;115:1345-54.

11. Jackson MJ. Physiology of zinc: general aspects. In: Mills CF, ed. Zinc in Human Biology. London: Springer-Verlag, 1989:1-14.

12. Hambidge KM, Casey CE, Krebs NF. Zinc. In: Mertz W, ed. Trace Elements in Human and Animal Nutrition, 5th edn. Toronto: Academic Press Inc, 1986:1-137. and depressed cytoxic responses have been reported in zinc-deficient mice, although increased natural killer activity with zinc deficiency has also been reported. This defective chemotaxis in mammals indicates that neutrophil function is also affected by zinc deficiency $(56,57)$.

The immunological changes observed in zinc-deficient humans and animals may be largely responsible for increased susceptibility to infection. Data obtained by numerous researchers demonstrate an increased susceptibility of zincdeficient animals to viral, parasitic and bacterial challenges (45). Virtually all immunological abnormalities discussed above are rapidly corrected following zinc repletion (51). There is, however, a notable exception: immunological

13. Bettger WJ, O’Dell BL. A critical physiological role of zinc in the structure and function of biomembranes. Life Sci 1981;28:1425-38.

14. Oh SH, Nakaue H, Deagen JT, Whanger PD, Arscott GH. Accumulation and depletion of zinc in chick tissue metallothioneins. J Nutr 1979;109:1720-9.

15. Shaw JCL. Trace elements in the foetus and young infant. Am J Dis Child 1979;13:1260-8.

16. Sanstead HH, Henriksen LK, Greger JL, Prasad AS, Good RA. Zinc nutriture in the elderly in relation to taste acuity, immune response, and wound healing. Am J Clin Nutr 1982;36:1046-59.

17. Vir SC, Love AHG. Zinc and copper status of the elderly. Am J Clin Nutr 1979;32:1472-6.

18. Wagner PA, Krista ML, Bailey LB. Zinc status of elderly black Americans from urban low-income households. Am J Clin Nutr 1980;33:1771-7.

19. Odne ML, Lee SC, Jeffrey LP. Rationale for adding trace elements to total parenteral nutrient solutions a brief review. Am J Hosp Pharm 1978;35:1057-9.

20. Underwood EJ. Trace metals in human and animal health. J Hum Nutr 1981;35:37-48

21. Lee HH, Prasad AS, Brewer GJ, Owyang C. Zinc absorption in human small intestine. Am J Physiol 1989;256:G87-91

22. Eckhart CD, Hurley LC. Reduced DNA synthesis in zinc deficiency: regional differences in embryonic rats. J Nutr 1977;107:855-61.

23. Duncan JR, Dreosti IE. The effect of memory that is lost due to postnatal zinc deficiency may not be fully recovered upon zinc repletion (55).

The importance of zinc as a micronutrient can be seen in the vast variety of essential physiological functions it performs (Table 2). This importance has served to further the interest in the biological roles of zinc and its nutritional significance. Preceding reports have given an overview of current knowledge regarding the role of zinc in basic physiological and biochemical processes. Further investigation is necessary if the precise mechanisms underlying the role of zinc in the normal function of the human organism, as well as its role in disease processes, are to be clarified.

zinc deficiency on the timing of deoxyribonucleic acid synthesis in regenerating rat liver. S Afr Med J 1974:48:1697-9.

24. Lieberman I, Abrams R, Hunt N, Ove P. Levels of enzyme activity and deoxyribonucleic acid synthesis in mammalian cells cultured from the animal. J Biol Chem 1963;238:3955-62.

25. Dreosti IE, Record IR, Manuel SJ. Incorporation of ${ }^{3} \mathrm{H}$-thymidine into DNA and the activity of alkaline phosphatase in zinc deficient fetal rat brains. Biol Trace Elem Res 1980;2:21-9.

26. Dreosti IE, Record IR, Manuel SJ. Zinc deficiency and the developing embryo. Biol Trace Elem Res 1985;7:103-22.

27. Duncan JR, Hurley LS. Thymidine kinase and DNA polymerase activity in normal and zinc deficient developing rat embryos. Proc Soc Exp Biol Med 1978;159:39-43.

28. Pardee AB, Coppock DL, Yang HC. Regulation of cell proliferation at the onset of DNA synthesis. J Cell Sci 1986;4(Suppl):171-80.

29. Sen D, Crothers DM. Condensation of chromatin: role of multivalent cations. Biochemistry 1986;25:1495-503.

30. Clegg MS, Keen CL, Hurley LS. Biochemical pathologies of zinc deficiency. In: Mills CF, ed. Zinc in Human Biology. London: Springer-Verlag, 1989:129-45.

31. Shin YA, Eckhhorn GL. Interactions of metal ions with polynucleotides and related compounds. XI. The reversible unwinding and rewinding of deoxyribonucleic acid by zinc (II) ions through temperature manipulation. Biochemistry 1968;7:1026-32. 
32. Fazakerley GV. Zinc Z-DNA. Nucleic Acids Res 1984;12:3643-8.

33. Castro CE, Alvares OF, Sevall J. Zinc deficiency decreases histone $\mathrm{H}^{\circ}{ }^{\circ}$ in rat liver. Nutr Rep Int 1986;34:67-74.

34. Falchuck KH, Mazus B, Ber E, Ulpino-Lobb L, Vallee BL. Zinc deficiency and the Euglena gracilis chromatin: formation of an alpha-amantin resistant RNA polymerase II. Biochemistry 1985;24:2576-80.

35. Terhune MW, Sanstead HH. Decreased RNA polymerase activity in mammalian zinc deficiency. Science 1972;177:68-9.

36. Okada A, Takagi Y, Nezu R, Lee S. Zinc in clinical surgery. Jpn J Surg 1990;20:635-44

37. Hambidge KM. Zinc in the nutrition of children. In: Chandra RK, ed. Trace Elements in the Nutrition of Children - II. New York: Raven Press, 1991:65-77.

38. Walravens PA, Krebs NF, Hambidge KM. Linear growth of low income preschool children receiving a zinc supplement. Am J Clin Nutr 1983;38:195-201.

39. Oner G, Bhaumick B, Bala RM. Effect of zinc deficiency on serum somatomedin levels and skeletal growth in young rats. Endocrinology 1984;114:1860-3.

40. Kynast G, Saling E. The relevance of zinc in pregnancy. J Perinat Med 1980;8:171-6.

41. Neggers YH, Cutter GR, Acton RT, et al. A positive association between maternal serum zinc concentration and birth weight. Am J Clin Nutr 1990;51:678-84.

42. Sandstead HH, Prasad AS, Schulert AR, et al. Human zinc deficiency endocrine manifestations and response to treatment. Am J Clin Nutr 1967;20:422-42.

43. Kinlaw WB, Levine AS, Morley JE, Silvis SE, McClain CJ. Abnormal zinc metabolism in type II diabetes mellitus. Am J Med 1983;75:273-7.

44. Canfield WK, Hambidge KM, Johnson LK. Zinc nutriture in type I diabetes mellitus: relationship to growth measures and metabolic control. J Pediatr Gastroenterol Nutr 1984;3:577-84.

45. Keen CL, Gershwin ME. Zinc deficiency and immune function. Annu Rev Nutr 1990;10:415-31.

46. Dowd PS, Kelleher J, Guillou PJ. T-lymphocyte subsets and interleukin-2 production in zinc-deficient rats. Br J Nutr 1986;55:59-69.

47. Flynn A. Control of in vitro lymphocyte proliferation by copper, magnesium, and zinc deficiency. J Nutr 1984;114:2034-42.

48. Salas M, Kirchner H. Induction of interferon-gamma in human leukocyte cultures stimulated by $\mathrm{Zn}^{+2}$. Clin Immunol Immunopathol 1987;45:139-42.

49. Montgomery DW, Chvapil M, Zukoski CF. Effects of zinc chloride on guinea pig complement component activity in vitro: concentration-dependent inhibition and enhancement. Infect Immun 1979;23:424-31.

50. Beach RS, Gershwin ME, Hurley LS. Growth and development of postnatally zinc-deprived mice. J Nutr 1980;110:201-11.

51. Chandra RK, Dayton DH. Trace element regulation of immunity and infection. Nutr Res 1982;2:721-33.

52. Good RA, West A, Day NK, Dong ZW, Fernandez G. Effects of undernutrition on host cell and organ function. Cancer Res 1982;42:737-43.

53. Bach JF. The multifaceted zinc dependency of the immune system. Immunol Today 1981;2:225-7.

54. Gross RL, Osdin N, Fong L, Newberne PM. Depressed immunological function in zinc-deprived rats as measured by mitogen response of spleen, thymus and peripheral blood. Am J Clin Nutr 1979;32:1260-5.

55. Fraker PJ, Caruso R, Kierszenbaum F. Alteration in the immune and nutritional status of mice by synergy between zinc deficiency and infection with Trypanosoma cruzi. J Nutr 1982;112:1224-9.

56. Haynes DC, Gershwin ME, Golub MS, et al. Studies of marginal zinc deprivation in rhesus monkeys. VI. Influence on the immunohematology of infants in the first year. Am J Clin Nutr 1985;42:252-62.

57. Weston WL, Huff JC, Humbert JR, Hambidge KM. Zinc correction of defective chemotaxis in acrodermatitis enteropathica. Arch Dermatol 1977;113:422-5.

58. Prasad AS. Deficiency of zinc in man and its toxicity. In: Prasad AS, ed. Trace Elements in Human Health and Disease, vol 1. Zinc and Copper. New York: Academic Press, 1976:1-20. 


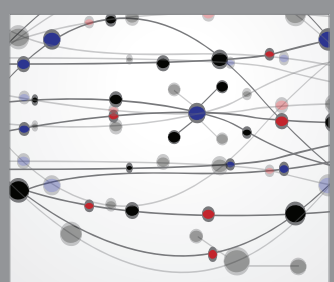

The Scientific World Journal
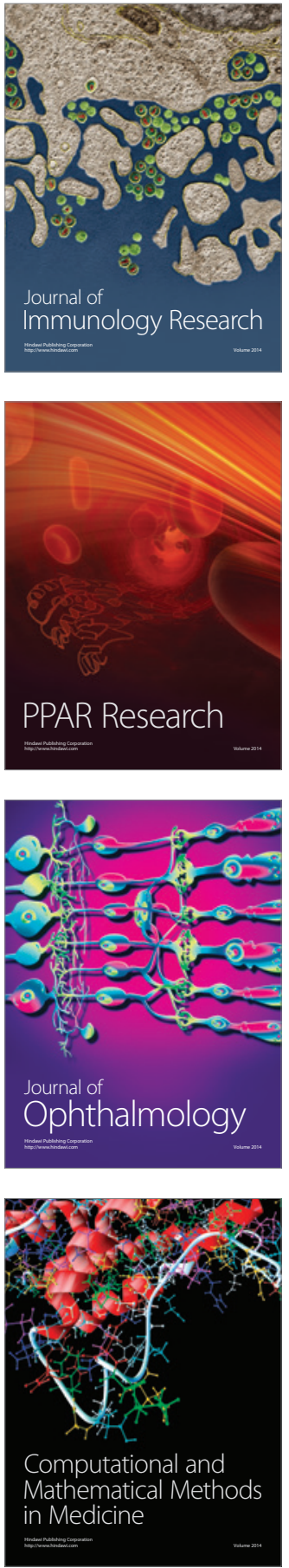

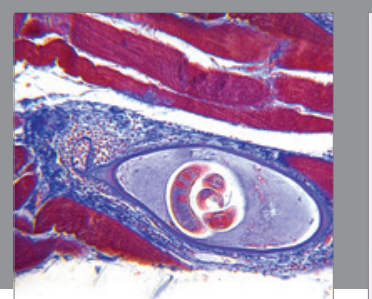

Gastroenterology Research and Practice

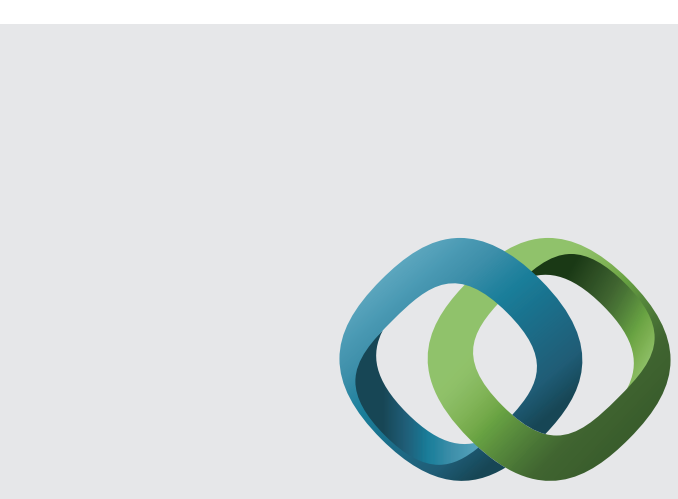

\section{Hindawi}

Submit your manuscripts at

http://www.hindawi.com
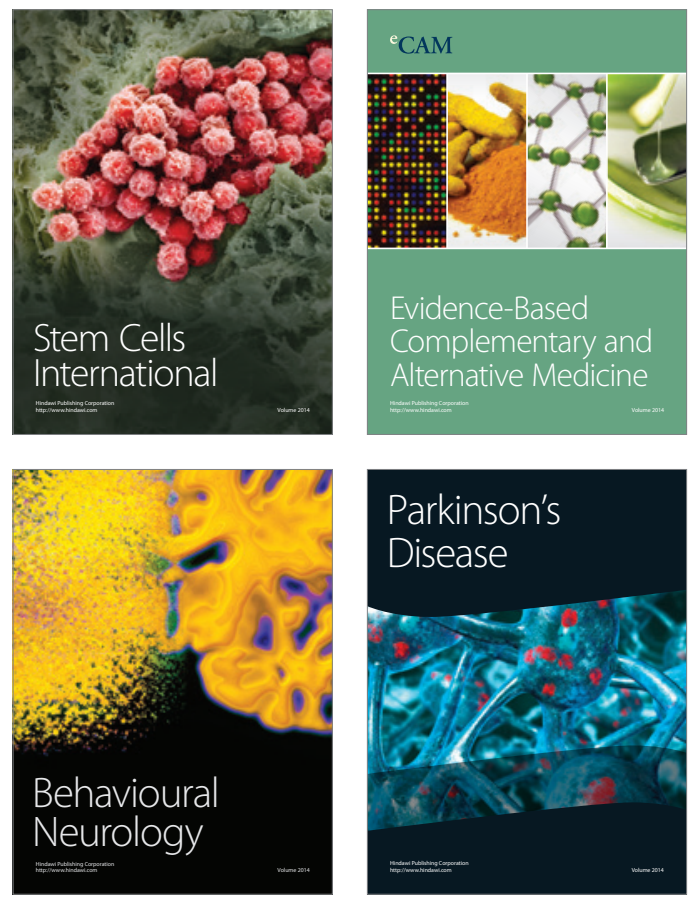
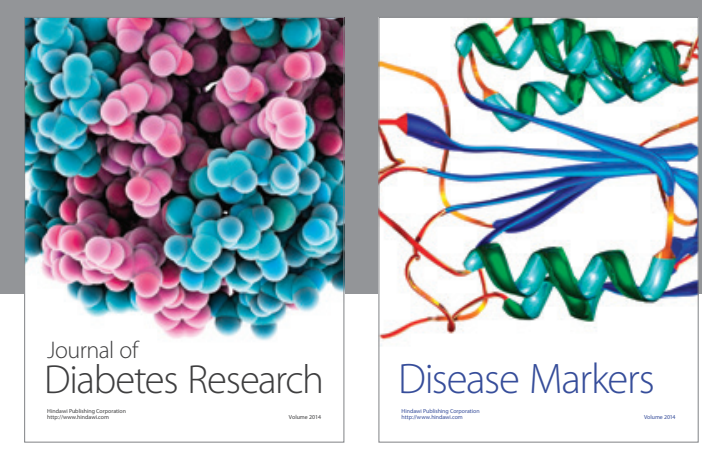

Disease Markers
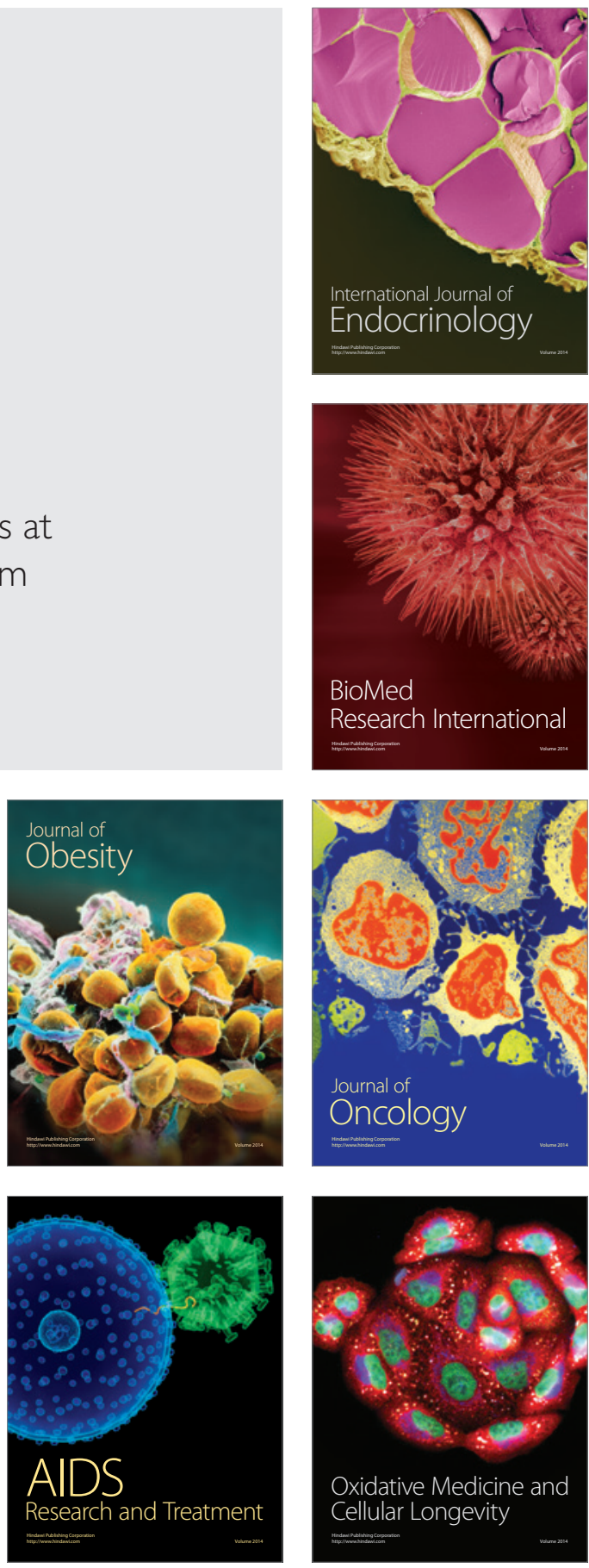